\title{
Pengaruh Profitabilitas, Hutang dan Ukuran Perusahaan terhadap Nilai Perusahaan Makanan dan Minuman
}

\author{
I Putu Pranata Eka Putra ${ }^{1}$ \\ Fakultas Ekonomi dan Bisnis \\ Universitas Udayana, Indonesia
}

\author{
I Made Pande Dwiana Putra ${ }^{2}$ \\ Fakultas Ekonomi dan Bisnis \\ Universitas Udayana, Indonesia
}

\begin{abstract}
Surel : pranataeka08@gmail.com
\section{ABSTRAK}

Tujuan dari penelitian ini yaitu untuk mendapatkan bukti empiris pengaruh profitabilitas, hutang, dan ukuran perusahaan terhadap nilai perusahaan makanan dan minuman. Penelitian ini dilakukan pada seluruh perusahaan makanan dan minuman yang terdaftar di Bursa Efek Indonesia (BEI) periode 2015-2018 yang berjumlah 13 sampel perusahaan. Metode penentuan sampel yang digunakan dalam penelitian ini adalah purposive sampling dan teknik analisis data dalam penelitian ini menggunakan analisis regresi linear berganda. Berdasarkan analisis yang dilakukan ditemukan bahwa profitabilitas, hutang, dan ukuran perusahaan berpengaruh positif terhadap nilai perusahaan.
\end{abstract}

Kata Kunci: Profitabilitas; Hutang; Ukuran Perusahaan; Nilai Perusahaan.

The Effect of Profitability, Debt and Company Size on the Value of Food and Beverage Companies Listed on the IDX

\section{ABSTRACT}

The purpose of this study is to obtain empirical evidence of the influence of profitability, debt, and company size on the value of food and beverage companies. This research was conducted in all food and beverage companies listed on the Indonesia Stock Exchange (IDX) for the 2015-2018 period, amounting to 13 sample companies. The sampling method used in this study was purposive sampling and data analysis techniques in this study used multiple linear regression analysis. Based on the analysis conducted, it was found that profitability, debt, and company size had a positive effect on firm value.

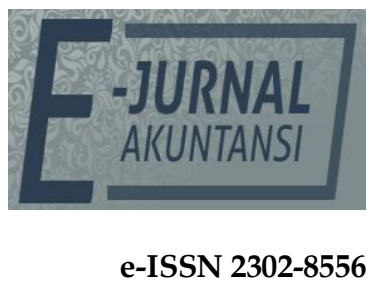

Vol. 30 No. 8

Denpasar, Agustus 2020 Hal. 2115-2126

DOI:

10.24843/EJA.2020.v30.i08.p17

PENGUTIPAN:

Putra, I P. P. E. \& Putra, I M. P. D. (2020). Pengaruh Profitabilitas, Hutang dan Ukuran Perusahaan terhadap Nilai Perusahaan Makanan dan Minuman. E-Jurnal Akuntansi, $30(8), 2115-2126$

RIWAYAT ARTIKEL:

Artikel Masuk: 4 Mei 2020 Artikel Diterima: 30 Juli 2020

Keywords: $\quad$ Profitability; Debt; Company Size; The Value Of The Company.

Artikel dapat diakses : https://ojs.unud.ac.id/index.php/Akuntansi/index 


\section{PENDAHULUAN}

Memaksimalkan nilai perusahaan sangat penting artinya bagi suatu perusahaan, karena dengan memaksimalkan nilai perusahaan berarti juga memaksimalkan kemakmuran pemegang saham yang merupakan tujuan utama perusahaan. Nilai perusahaan sangat penting karena mencerminkan kinerja perusahaan yang dapat mempengaruhi persepsi investor terhadap perusahaan. Perusahaan yang menerapkan prinsip-prinsip ekonomi umumnya tidak hanya berorientasi pada pencapaian laba maksimal, tetapi juga berusaha meningkatkan nilai perusahaan dan kemakmuran pemiliknya (Safitri, 2016).

Nilai perusahaan yang tinggi akan membuat rasa percaya seorang investor terhadap nilai perusahaan akan meningkat. Nilai perusahaan tidak hanya dapat digambarkan pada harga saham suatu perusahaan saja, untuk mengukur tingginya nilai perusahaan dapat dilakukan dengan berbagai cara. Nilai perusahaan dalam penelitian ini diukur dengan menggunakan Tobin's $Q$. Menurut Sudiyatno \& Puspitasari (2010), Tobin's $Q$ adalah indikator untuk mengukur kinerja perusahaan, khususnya tentang nilai perusahaan yang menunjukkan suatu performa manajemen dalam mengelola aktiva perusahaan. Tobin's $Q$ merupakan perbandingan antara nilai pasar ditambah total utang terhadap aset.

Teori sinyal menjelaskan mengapa perusahaan memiliki insentif untuk mempublikasikan informasi kepada pihak luar. Dorongan ini disebabkan oleh asimetri informasi (informasi asimetris) antara perusahaan dan pihak eksternal (Wiagustini et al., 2017). Informasi yang dimaksud dalam hal ini adalah mengenai bagaimana suatu perusahaan dapat meningkatkan profitabilitas dan bagaimana perusahaan dapat menjalankafn operasionalnya dengan baik melalui pengelolaan hutang yang efektif dan efisien. Informasi tersebut diharapkan dapat memberi sinyal yang positif bagi investor tentang kondisi perusahaan, dengan demikian investor akan percaya untuk menanamkan modalnya di perusahaan tersebut sehingga nilai perusahaan bisa meningkat.

Perusahaan makanan dan minuman dipilih sebagai objek penelitian yaitu dikarenakan perusahaan makanan dan minuman sendiri adalah salah satu sektor perusahaan yang paling stabil. Sektor ini juga tidak mudah terpengaruh oleh musim ataupun perubahan kondisi perekonomian. Selain itu perusahaan makanan dan minuman memberikan kontribusi yang besar terhadap pertumbuhan ekonomi nasional dan capaian kinerjanya tercatat konsisten, dari peningkatan produktivitas, investasi sampai ekspor. Menurut Yanti \& Darmayanti (2019), kelancaran produk industri makanan dan minuman akan tetap terjamin karena sektor ini bergerak pada bidang industri pokok manusia. Hal ini disebabkan karena kebutuhan akan makanan dan minuman yang tidak akan pernah berhenti dalam kondisi apapun. Di Indonesia, jumlah penduduk dari tahun ke tahun terus meningkat dan juga kebutuhan akan makanan dan minuman ini akan terus dibutuhkan. Perusahaan harus bisa mendapat kepercayaan investor agar investor mau menanamkan modalnya di perusahaan tersebut.

Hasil penelitian sebelumnya, mengenai pengaruh profitabilitas terhadap nilai perusahaan dilakukan oleh Chen \& Chen (2011), Riaz \& Qasim (2016), Purwohandoko (2017) membuktikan bahwa profitabilitas berpengaruh positif 
dan siginifikan terhadap nilai perusahaan. Terdapat hal yang berbeda dalam penelitian yang dilakukan oleh Gusaptono (2010), Herawati (2013), Sabrin et al., (2016) yang membuktikan bahwa profitabilitas memiliki pengaruh negatif dan signifikan terhadap nilai perusahaan.

Hasil penelitian sebelumnya mengenai hutang yang dilakukan Cheng \& Tzeng (2011) dan Septariani (2017) menunjukkan bahwa hutang berpengaruh positif terhadap nilai perusahaan. Sedangkan hasil yang berbeda ditunjukkan pada penelitian yang dilakukan Putri \& Ukhriyawati (2016) yang menunjukkan bahwa hutang berpengaruh negatif terhadap nilai perusahaan.

Hasil penelitian sebelumnya mengenai ukuran perusahaan yang dilakukan oleh Rizqia et al., (2013), Novari \& Lestari (2016) yang menyatakan bahwa ukuran perusahaan berpengaruh positif dan signifikan terhadap nilai perusahaan. Sedangkan hasil penelitian yang dilakukan Farooq \& Masood (2016) dan Ramadhitya \& Dillak (2018) yang menyatakan bahwa ukuran perusahaan tidak berpengaruh terhadap nilai perusahaan.

Nilai perusahaan dapat pula dipengaruhi oleh besar kecilnya profitabilitas yang dihasilkan oleh perusahaan. Profitabilitas berperan penting dalam semua aspek bisnis karena dapat menunjukkan efisiensi dari perusahaan dan mencerminkan kinerja perusahaan. Tingkat profitabilitas yang tinggi dijadikan tolak ukur apakah suatu perusahaan dapat bertahan lama dengan memperoleh laba yang memadai dibanding risikonya. Teori sinyal memiliki hubungan dengan profitabilitas yaitu tentang bagaimana manajemen memberikan informasi kepada para investor mengenai laba yang dihasilkan perusahaan sehingga investor mengetahui bagaimana prospek kedepan perusahaan yang mereka tanamkan modalnya.

Penelitian yang dilakukan oleh Rachmawati \& Pinem (2015) menunjukkan bahwa profitabilitas memiliki pengaruh positif dan signifikan terhadap nilai perusahaan. Penelitian dilakukan pada industri dasar dan kimia di Bursa Efek Indonesia periode 2013-2014. Hasil penelitian ini sejalan dengan penelitian yang dilakukan oleh Dewi \& Wirajaya (2013) dan (Susanto, 2016).

$\mathrm{H}_{1}$ : Profitabilitas berpengaruh positif terhadap nilai perusahaan.

Suatu perusahaan tentunya memerlukan dana untuk dapat menjalankan usahanya. Hutang digambarkan untuk melihat seberapa jauh aset perusahaan dibiayai oleh utang dibandingkan dengan modal sendiri. Utang merupakan salah satu sumber pembiayaan eksternal yang digunakan oleh perusahaan untuk membiayai kebutuhan dananya. Perusahaan yang menggunakan utang mempunyai kewajiban atas beban bunga dan beban pokok pinjaman. Perusahaan yang baik harusnya memiliki komposisi modal yang lebih besar dibandingkan utangnya. Semakin besar nilai hutang suatu perusahaan maka akan semakin tinggi pula risikonya karena pendanaan dari unsur utang lebih besar daripada unsur modal sendiri. Teori keagenan memiliki hubungan dengan hutang yaitu dimana manajemen perusahaan ingin mendapatkan dana sebanyakbanyaknya melalui utang, sedangkan para pemilik perusahaan tidak menyukai keputusan manajemen untuk mendapat dana sebanyak-banyaknya melalui utang karena tingkat utang yang tinggi akan berpengaruh terhadap laba sehingga nilai perusahaan akan turun. 
Penelitian yang dilakukan Ramadhitya \& Dillak (2018) menunjukkan bahwa hutang memiliki pengaruh positif dan signifikan terhadap nilai perusahaan, dimana penelitian ini dilakukan pada sub sektor makanan dan minuman di Bursa Efek Indonesia pada periode 2012-2016.

$\mathrm{H}_{2}$ : Hutang berpengaruh positif terhadap nilai perusahaan.

Ukuran perusahaan dapat tercermin dari berbagai hal, salah satunya yaitu dari total aset yang dimiliki suatu perusahaan. Semakin besar ukuran atau skala perusahaan maka akan semakin mudah perusahaan tersebut memperoleh sumber pendanaan baik itu dari internal perusahaan maupun eksternal perusahaan. Ukuran perusahaan yang besar mencerminkan bahwa perusahaan dengan pertumbuhan yang besar akan memperoleh kemudahan untuk memasuki pasar modal karena akan meningkatkan ketertarikan investor untuk menanamkan modalnya. Selain itu perusahaan dengan skala ukuran yang besar, maka akan berdampak pada naiknya harga saham dan nilai perusahaan pun akan tinggi sehingga mereka mampu melunasi total utangnya dengan jumlah aset yang besar. Teori sinyal memiliki hubungan dengan ukuran perusahaan yaitu dimana manajemen harus memberi informasi yang sama mengenai ukuran perusahaan melalui total aset atau total penjualan yang dimiliki perusahaan kepada para pemegang saham sehingga investor dapat mengetahui bagaimana prospek kedepan perusahaan yang mereka tanamkan modalnya.

Penelitian yang dilakukan oleh Novari \& Lestari (2016) yang menunjukkan bahwa ukuran perusahaan memiliki pengaruh positif dan signifikan terhadap nilai perusahaan, dimana penelitian ini dilakukan pada sektor properti dan real estate di Bursa Efek Indonesia pada periode 2012-2014. Penelitian ini juga sejalan dengan penelitian yang dilakukan Tui et al,. (2017) yang menunjukkan bahwa ukuran perusahaan memiliki pengaruh positif terhadap nilai perusahaan. $\mathrm{H}_{3}$ : Ukuran perusahaan berpengaruh positif terhadap nilai perusahaan.

\section{METODE PENELITIAN}

Penelitian ini dilakukan pada perusahaan makanan dan minuman yang terdaftar di Bursa Efek Indonesia (BEI) periode 2015-2018 yang diakses resmi di situs Bursa Efek Indonesia (www.idx.co.id) dan situs resmi perusahaan yang bersangkutan. Objek dalam penelitian ini adalah profitabilitas, hutang dan ukuran perusahaan.

Nilai perusahaan pada sektor makanan dan minuman di Bursa Efek Indonesia (BEI) periode 2015-2018 dalam penelitian ini diukur dengan menggunakan Tobin's $Q$ yang membandingkan antara nilai pasar ditambah total utang dibagi dengan total aset. Adapun Tobin's $Q$ dapat dihitung dengan rumus sebagai berikut.

$$
\text { Tobin's } Q=\frac{\text { MVS }+D E B T}{\text { Total Aset }}
$$

Profitabilitas pada perusahaan sektor makanan dan minuman di Bursa Efek Indonesia (BEI) periode 2015-2018 dalam penelitian ini diukur menggunakan Return On Assets (ROA) yang mengukur return atas modal sendiri. Adapun Return On Assets (ROA) dapat dihitung dengan rumus sebagai berikut.

$$
\text { ROA }=\frac{\text { Laba Bersih }}{\text { Total Asset }} \times 100 \%
$$


Hutang pada perusahaan sektor makanan dan minuman di Bursa Efek Indonesia (BEI) periode 2015-2018 dalam penelitian ini diukur menggunakan Debt to Assets Ratio (DAR) karena DAR membandingkan total utang dengan total aset yang dimiliki perusahaan. Debt to Assets Ratio (DAR) dapat dihitung dengan rumus sebagai berikut.

$$
\text { DAR }=\frac{\text { Total Utang }}{\text { Total Aset }} \times 100 \%
$$

Variabel ukuran perusahaan pada perusahaan sektor makanan dan minuman di Bursa Efek Indonesia (BEI) periode 2015-2018 dalam penelitian ini diukur menggunakan nilai logaritma natural (Ln) dari penjualan atau sales. Ukuran perusahaan dapat dihitung dengan rumus sebagai berikut.

Ukuran Perusahaan = Ln (Sales)

Populasi yang digunakan dalam penelitian ini adalah seluruh perusahaan makanan dan minuman yang terdaftar di Bursa Efek Indonesia (BEI). Periode penelitian yang digunakan adalah dari tahun 2015-2018. Teknik pengambilan sampel yang digunakan dalam penelitian ini adalah teknik non probability sampling, dimana teknik tersebut merupakan teknik pengambilan sampel yang dilakukan secara tidak acak sehingga elemen-elemen populasi tidak mempunyai kesempatan yang sama untuk terpilih menjadi sampel.

Analisis regresi linier berganda digunakan untuk mengetahui pengaruh dari variabel-variabel independen yaitu profitabilitas $\left(X_{1}\right)$, hutang $\left(X_{2}\right)$, dan ukuran perusahaan $\left(X_{3}\right)$ terhadap variabel dependen yaitu nilai perusahaan ( $Y$ ). Data dalam penelitian ini akan dianalisis dengan uji statistik deskriptif, uji regresi linear berganda, uji koefisien determinasi, uji asumsi klasik, uji kelayakan model dan uji hipotesis. Data dalam penelitian ini akan diuji melalui aplikasi pengolahan data SPSS (Statistic Package for Social Sciences). Uji regresi linier berganda dirumuskan sebagai berikut:

$Y=\alpha+\beta_{1} X_{1}+\beta_{2} X_{2}+\beta_{3} X_{3}+\varepsilon i$

Keterangan:

$\begin{array}{ll}\mathrm{Y} & : \text { Nilai Perusahaan } \\ \mathrm{a} & : \text { Konstanta } \\ \beta_{1,2,3} & : \text { Penaksiran koefisien regresi } \\ \mathrm{X}_{1} & \text { : Profitabilitas } \\ \mathrm{X}_{2} & : \text { Hutang } \\ \mathrm{X}_{3} & : \text { Ukuran Perusahaan } \\ \varepsilon \mathrm{i} & : \text { Standar eror }\end{array}$

\section{HASIL DAN PEMBAHASAN}

Statistik deskriptif merupakan statistik yang digunakan untuk menganalisis data dengan cara mendeskripsikan atau menggambarkan data yang telah terkumpul. Statistik deskriptif disajikan untuk memberikan informasi mengenai karakteristik variabel-variabel penelitian, yaitu jumlah sampel, nilai minimum, nilai maksimum, nilai rata-rata, dan standar deviasi. Hasil statistik deskriptif penelitian ini dapat dilihat pada Tabel 1, berikut. 
Tabel 1. Hasil Statistik Deskriptif

\begin{tabular}{llllll}
\hline & N & Minimum & Maximum & Mean & $\begin{array}{l}\text { Std. } \\
\text { Deviation }\end{array}$ \\
\hline ROA (\%) & 52 & $-6,87$ & 52,67 & 9,3140 & 10,97398 \\
DAR & 52 & 0,15 & 0,68 & 0,4475 & 0,15329 \\
SALES & 52 & 26,29 & 31,93 & 28,8406 & 1,52813 \\
TOBINSQ & 52 & 0,76 & 12,26 & 2,8502 & 2,66864 \\
\hline
\end{tabular}

Sumber: Data Penelitian, 2019

Variabel nilai perusahaan (Y) menggunakan Tobin's $Q$ sebagai proksi. Hasil analisis statistik deskriptif menunjukkan nilai minimum Tobin's $Q$ sebesar 0,76 memiliki arti bahwa nilai pasar berbanding dengan nilai buku bernilai 0,76 kali. Sedangkan nilai maksimum Tobin's $Q$ sebesar 12,26 memiliki arti bahwa nilai pasar berbanding dengan nilai buku sebesar 12,26 kali. Nilai rata-rata Tobin's $Q$ sebesar 2,8502. Hal ini berarti rata-rata nilai perusahaan dari 52 perusahaan makanan dan minuman sebesar 2,8502. Standar deviasi sebesar 2,66864 memiliki arti bahwa adanya penyimpangan nilai perusahaan dari nilai rata-ratanya sebesar 2,66864.

Variabel profitabilitas diproksikan dengan Return On Assets (ROA). Hasil analisis statistik deskriptif pada ROA menunjukkan nilai minimum sebesar -6,87 persen dan nilai maksimum sebesar 52,67 persen. Nilai rata-rata dari ROA sebesar 9,3140 persen. Hal ini berarti rata-rata profitabilitas dari 52 perusahaan makanan dan minuman sebesar 9,3140 persen. Standar deviasi dari ROA sebesar 10,97398 yang berarti terjadi penyimpangan profitabilitas terhadap nilai rata-rata sebesar 10,97398.

Variabel hutang diproksikan dengan Debt to Assets Ratio (DAR). Hasil analisis statistik deskriptif pada DAR menunjukkan nilai minimum sebesar 0,15 dan nilai maksimum sebesar 0,68. Nilai rata-rata dari DAR sebesar 0,4475. Hal ini berarti rata-rata hutang dari 52 perusahaan makanan dan minuman sebesar 0,4475. Standar deviasi dari DAR sebesar 0,15329 yang berarti terjadi penyimpangan hutang terhadap nilai rata-rata sebesar 0,15329.

Variabel ukuran perusahaan diproksikan dengan Ln (sales). Hasil analisis statistik deskriptif pada Ln (sales) menunjukkan nilai minimum sebesar 26,29 dan nilai maksimum sebesar 31,93. Nilai rata-rata dari Ln (sales) sebesar 28,8406. Hal ini berarti rata-rata ukuran perusahaan dari 52 perusahaan makanan dan minuman sebesar 28,8406. Standar deviasi dari Ln (sales) sebesar 1,52813. Ini berarti terjadi penyimpangan ukuran perusahaan terhadap nilai rata-rata sebesar 1,52813 .

Analisis regresi linear berganda digunakan untuk mengetahui pengaruh dari variabel-variabel independen yaitu profitabilitas, hutang dan ukuran perusahaan terhadap variabel dependen yaitu nilai perusahaan. Data dalam penelitian ini akan dianalisis dengan uji statistik melalui aplikasi pengolahan data SPSS (Statistic Package for Social Sciences). Hasil uji regresi linear berganda disajikan dalam Tabel 2, berikut. 
Tabel 2. Hasil Uji Regresi Linear Berganda

\begin{tabular}{|c|c|c|c|c|c|}
\hline & \multicolumn{2}{|c|}{ Unstandardized Coefficients } & \multirow{2}{*}{$\begin{array}{l}\begin{array}{l}\text { Standardized } \\
\text { Coefficients }\end{array} \\
\text { Beta }\end{array}$} & \multirow[t]{2}{*}{$\mathrm{t}$} & \multirow[t]{2}{*}{ Sig. } \\
\hline & B & Std. Error & & & \\
\hline (Constant) & 0,068 & 0,056 & & 1,215 & 0,230 \\
\hline ROA & 0,465 & 0,105 & 0,448 & 4,409 & 0,000 \\
\hline DAR & 0,197 & 0,060 & 0,170 & 3,308 & 0,002 \\
\hline SALES & 0,480 & 0,096 & 0,508 & 5,000 & 0,000 \\
\hline
\end{tabular}

Sumber: Data Penelitian, 2019

Berdasarkan hasil analisis regresi linear berganda seperti pada Tabel 2, maka persamaan strukturalnya adalah sebagai berikut:

$$
\mathrm{Y}=0,068+0,465 \mathrm{X}_{1}+0,197 \mathrm{X}_{2}+0,480 \mathrm{X}_{3}+\varepsilon
$$

Nilai konstanta sebesar 0,068 memiliki arti bahwa apabila nilai variabel profitabilitas $\left(\mathrm{X}_{1}\right)$, hutang $\left(\mathrm{X}_{2}\right)$ dan ukuran perusahaan $\left(\mathrm{X}_{3}\right)$ bernilai konstan, maka variabel nilai perusahaan adalah sebesar 0,068 . Variabel profitabilitas $\left(X_{1}\right)$ memiliki koefisien regresi $\left(\beta_{1}\right)$ sebesar 0,465 memiliki arti apabila profitabilitas naik sebesar satu satuan, maka nilai perusahaan meningkat sebesar 0,465 dengan asumsi variabel independen lainnya bernilai konstan. Variabel hutang $\left(\mathrm{X}_{2}\right)$ memiliki koefisien regresi $\left(\beta_{2}\right)$ sebesar 0,197 memiliki arti apabila hutang naik sebesar satu satuan, maka nilai perusahaan meningkat sebesar 0,197 dengan asumsi variabel independen lainnya bernilai konstan. Variabel ukuran perusahaan $\left(X_{3}\right)$ memiliki koefisien regresi $\left(\beta_{3}\right)$ sebesar 0,480 memiliki arti apabila ukuran perusahaan naik sebesar satu satuan, maka nilai perusahaan meningkat sebesar 0,465 dengan asumsi variabel independen lainnya bernilai konstan.

Koefisien determinasi $\left(\mathrm{R}^{2}\right)$ digunakan untuk mengukur seberapa jauh kemampuan model dalam menerangkan variabel dependen. Nilai koefisien determinasi adalah antara nol dan satu. Pada penelitian ini, koefisien determinasi yang digunakan adalah nilai dari adjusted $R^{2}$, karena tidak seperti $R^{2}$, nilai adjusted $\mathrm{R}^{2}$ dapat naik atau turun apabila satu variabel independen ditambahkan ke dalam model. Hasil uji koefisien determinasi disajikan pada Tabel 3, berikut.

Tabel 3. Hasil Uji Koefisien Determinasi (Adjusted R²)

\begin{tabular}{lllll}
\hline & $\mathrm{R}$ & $\mathrm{R}$ Square & Adjusted R Square & Std. Error of the Estimate \\
\hline 1 & $0,940^{\mathrm{a}}$ & 0,883 & 0,876 & 0,35283397
\end{tabular}

Sumber: Data Penelitian, 2019

Hasil uji memberikan hasil dimana diperoleh besarnya adjusted $\mathrm{R}^{2}$ pada Tabel 3, adalah 0,876. Ini berarti variasi nilai perusahaan pada perusahaan makanan dan minuman yang terdaftar di Bursa Efek Indonesia (BEI) pada tahun 2015-2018 dapat dipengaruhi secara signifikan oleh variabel profitabilitas $\left(X_{1}\right)$, hutang $\left(X_{2}\right)$, dan ukuran perusahaan $\left(X_{3}\right)$ sebesar $87,6 \%$ sedangkan sisanya sebesar $12,4 \%$ dijelaskan oleh faktor-faktor lain.

Uji kelayakan model dalam penelitian ini menggunakan uji F. Uji statistik F pada dasarnya menunjukkan apakah semua variabel bebas yang dimasukkan dalam model mempunyai pengaruh secara bersama-sama terhadap variabel terikat. Model regresi dinyatakan layak apabila sig. $\mathrm{F}<$ a $(5 \%)$. Hasil uji $\mathrm{F}$ disajikan pada Tabel 4, sebagai berikut. 
Tabel 4. Hasil Uji Kelayakan Model (Uji F)

\begin{tabular}{llllll}
\hline & Sum of Squares & Df & Mean Square & F & Sig. \\
\hline Regression & 45,024 & 3 & 15,008 & 120,555 & $0,000^{\mathrm{a}}$ \\
Residual & 5,976 & 48 & 0,124 & & \\
Total & 51,000 & 51 & & & \\
\hline
\end{tabular}

Sumber: Data Penelitian, 2019

Berdasarkan Tabel 4, dapat dilihat bahwa signifikan uji $\mathrm{F}$ yaitu sebesar 0,000 lebih kecil dari 5\%, sehingga dapat disimpulkan bahwa regresi linear yang diestimasi layak digunakan untuk menjelaskan pengaruh profitabilitas, hutang, dan ukuran perusahaan terhadap nilai perusahaan.

Uji hipotesis dalam penelitian ini menggunakan uji t. Uji regresi parsial ( $t-$ test) digunakan untuk mengetahui apakah model regresi variabel independen secara parsial berpengaruh signifikan terhadap variabel dependen. Hasil uji $t$ disajikan pada Tabel 5, sebagai berikut.

Tabel 5. Hasil Uji Hipotesis (Uji t)

\begin{tabular}{lll}
\hline Variabel & B & Sig. \\
\hline (Constant) & 0,068 & 0,230 \\
ROA & 0,465 & 0,000 \\
DAR & 0,197 & 0,002 \\
SALES & 0,480 & 0,000 \\
\hline
\end{tabular}

Sumber: Data Penelitian, 2019

Variabel profitabilitas $\left(\mathrm{X}_{1}\right)$ memiliki nilai signifikansi sebesar 0,000 dengan $\beta$ sebesar 0,465 . Nilai siginifkansi 0,000 lebih kecil dari tingkat kesalahan yang dapat diterima yaitu $5 \%$ atau $(0,000)<(0,05)$ mengindikasikan bahwa $\mathrm{H}_{1}$ diterima. Hal ini memiliki arti bahwa profitabilitas $\left(X_{1}\right)$ secara parsial berpengaruh pada nilai perusahaan.

Variabel hutang $\left(X_{2}\right)$ memiliki nilai signifikansi sebesar 0,002 dengan $\beta$ sebesar 0,197. Nilai signifkansi 0,002 lebih kecil dari tingkat kesalahan yang dapat diterima yaitu $5 \%$ atau $(0,002)<(0,05)$ mengindikasikan bahwa $\mathrm{H}_{2}$ diterima. Hal ini memiliki arti bahwa hutang $\left(X_{2}\right)$ secara parsial berpengaruh pada nilai perusahaan.

Variabel ukuran perusahaan $\left(X_{3}\right)$ memiliki nilai signifikansi sebesar 0,000 dengan $\beta$ sebesar 0,480 . Nilai signifikansi 0,000 lebih kecil dari tingkat kesalahan yang dapat diterima yaitu $5 \%$ atau $(0,000)<(0,05)$ mengindikasikan bahwa $\mathrm{H}_{3}$ diterima. Hal ini memiliki arti bahwa ukuran perusahaan $\left(X_{3}\right)$ secara parsial berpengaruh signifikan pada nilai perusahaan.

Hipotesis pertama penelitian ini menyatakan bahwa profitabilitas berpngaruh positif terhadap nilai perusahaan. Berdasarkan hasil uji regresi linear berganda diketahui bahwa profitabilitas dengan nilai koefisien positif, berarti semakin besar nilai profitabilitas suatu perusahaan maka semakin tinggi kemampuan perusahaan menghasilkan laba, maka semakin besar pula return yang diharapkan investor sehingga mengakibatkan nilai perusahaan akan meningkat. Dengan demikian, $\mathrm{H}_{1}$ yang menyatakan profitabilitas berpengaruh positif terhadap nilai perusahaan diterima.

Teori sinyal menjelaskan perusahaan mengeluarkan sinyal berupa pelaporan informasi keuangan terkait kinerja perusahaan dapat meningkatkan 
nilai perusahaan. Laporan keuangan yang dipublikasikan oleh perusahaan memuat berbagai informasi yang dibutuhkan investor, salah satunya laba perusahaan. Profitabilitas perusahaan yang tinggi akan mencerminkan prospek perusahaan yang baik dalam menghasilkan laba. Profitabilitas suatu perusahaan yang tinggi juga menunjukkan efisiensi dalam perusahaan sehingga terlihat bahwa kinerja perusahaan yang baik dan investor akan merespon positif sinyal tersebut dan meningkatkan nilai perusahaan. Hasil ini sejalan dengan hasil penelitian yang dilakukan oleh Chen \& Chen, (2011), Riaz \& Qasim, (2016) dan Purwohandoko, (2017) yang memperoleh hasil bahwa profitabilitas berpengaruh positif dan signifikan terhadap nilai perusahaan.

Hipotesis kedua penelitian ini menyatakan bahwa hutang berpengaruh positif terhadap nilai perusahaan. Berdasarkan hasil uji regresi linear berganda diketahui bahwa hutang dengan nilai koefisien positif, berarti semakin tinggi nilai DAR maka semakin besar pula jumlah aset yang dibiayai oleh utang. Hasil ini mempunyai arti bahwa hutang berpengaruh positif dan signifikan pada nilai perusahaan. Dengan demikian $\mathrm{H}_{2}$ yang menyatakan hutang berpengaruh positif terhadap nilai perusahaan diterima.

Teori yang mendukung hasil analisis ini adalah teori sinyal yang menyatakan bahwa perusahaan yang berkualitas baik akan memberikan sinyal pada pasar dengan demikian pasar diharapkan dapat membedakan perusahaan yang berkualitas baik dan buruk. Hutang memberikan informasi atau isyarat mengenai aktiva dan modal perusahan karena hutang yang tinggi akan meningkatkan keyakinan akan aktiva dan modal perusahaan. Hasil penelitian ini sejalan dengan penelitian sebelumnya yang dilakukan oleh Cheng \& Tzeng, (2011) dan Septariani, (2017) yang memperoleh hasil bahwa hutang berpengaruh positif dan signifikan terhadap nilai perusahaan.

Hipotesis ketiga penelitian ini menyatakan bahwa ukuran perusahaan berpengaruh positif terhadap nilai perusahaan. Berdasarkan hasil uji regresi linear berganda diketahui bahwa ukuran perusahaan dengan nilai koefisien positif, berarti semakin besar ukuran perusahaan atau skala perusahaan maka semakin mudah perusahaan tersebut memperoleh sumber pendanaan baik dari internal perusahaan maupun eksternal perusahaan. Hasil ini mempunyai arti bahwa ukuran perusahaan berpengaruh positif dan signifikan pada nilai perusahaan. Dengan demikian $\mathrm{H}_{3}$ yang menyatakan ukuran perusahaan berpengaruh positif terhadap nilai perusahaan diterima.

Hasil ini didukung oleh teori sinyal yang menjelaskan bahwa semakin besar ukuran perusahaan maka investor akan lebih tertarik untuk membeli sahamnya. Hal ini karena ukuran perusahaan yang besar merupakan sinyal bagi investor prusahaan memiliki kondisi keuangan yang lebih stabil dan lebih mudah mendapatkan sumber pendanaan sehingga akan lebih menarik bagi investopr untuk membeli sahamnya sehingga akan mendorong naiknya nilai perusahaan. Hasil penelitian ini sejalan dengan penelitian sebelumnya yang dilakukan oleh Rizqia et al., (2013), Novari \& Lestari, (2016) yang memperoleh hasil bahwa ukuran perusahaan berpengaruh positif dan signifikan terhadap nilai perusahaan. 


\section{SIMPULAN}

Penelitian ini diharapkan mampu memberikan kontribusi pada studi akuntansi dan pemahaman mengenai pengaruh profitabilitas, hutang, dan ukuran perusahaan pada nilai perusahaan. Hasil penelitian menunjukkan profitabilitas berpengaruh positif pada nilai perusahaan. Hal ini sesuai dengan teori sinyal yang menyatakan bahwa informasi terkait profitabilitas merupakan sinyal positif untuk menarik minat investor dalam berinvestasi dalam suatu perusahaan. Variabel hutang berpengaruh positif pada nilai perusahaan. Hal ini sesuai dengan teori sinyal yang menyatakan bahwa perusahaan yang berkualitas baik akan memberikan sinyal pada pasar dengan demikian pasar diharapkan dapat membedakan perusahaan yang berkualitas baik dan buruk. Variabel ukuran perusahaan berpengaruh positif pada nilai perusahaan. Hal ini sesuai dengan teori sinyal dimana semakin besar ukuran perusahaan maka investor akan lebih tertarik untuk membeli sahamnya.

Hasil penelitian ini diharapkan mampu memberikan kontribusi bagi semua pihak khususnya pihak investor dan perusahaan. Dapat disimpulkan bahwa untuk meningkatkan nilai perusahaan perlu adanya peningkatan profitabilitas, meningkatkan proporsi utang dan memperhatikan ukuran perusahaan, yang juga dilaporkan secara transparan agar menjadi sinyal yang positif bagi para investor atau stakeholder dan pihak lainnya yang berkepentingan.

Terkait standar koefisien pada hasil uji regresi linear berganda dapat dilihat bahwa nilai beta untuk hutang yang diproksikan dengan DAR memiliki nilai terkecil dibandingkan variabel lainnya, yaitu sebesar 0,170 . Hal ini dapat menjadi pertimbangan bagi investor karena semakin rendah nilai hutang yang dimiliki perusahaan maka risiko hutang yang dimiliki semakin rendah pula. Selain itu dilihat dari nilai $\mathrm{R}^{2}$ sebesar 0,876 berarti variasi perusahaan makanan dan minuman ini dipengaruhi secara signifikan oleh profitabilitas, hutang dan ukuran perusahaan.

\section{REFERENSI}

Chen, L.-J., \& Chen, S.-Y. (2011). The influence of profitability on firm value with capital structure as the mediator and firm size and industry as moderators. Investment Management and Financial Innovations, 8(3), 121-129.

Cheng, M.-C., \& Tzeng, Z.-C. (2011). The Effect of Leverage on Firm Value and How The Firm Financial Quality Influence on This Effect. World Journal of Management, 3(2), 30-53.

Dewi, A. S. M., \& Wirajaya, A. (2013). Pengaruh Struktur Modal, Profitabilitas Dan Ukuran Perusahaan Pada Nilai Perusahaan. E-Jurnal Akuntansi Universitas Udayana, 4(2), 358-372.

Farooq, M. A., \& Masood, A. (2016). Impact of Financial Leverage on Value of Firm : Evidence from Cement Sector of Pakistan. Research Journal Of Finance And Accounting, 7(9), 73-77.

Gusaptono, R. H. (2010). Faktor-Faktor Yang Mendorong Penciptaan Nilai Perusahaan Di BEI. Buletin Ekonomi, 8(2), 149-158.

Herawati, T. (2013). Pengaruh Kebijakan Dividen, Kebijakan Hutang Dan Profitabilitas Terhadap Nilai Perusahaan. Universitas Negeri Padang, 1-18. 
Novari, P. M., \& Lestari, P. V. (2016). Pengaruh Ukuran Perusahaan, Leverage, Dan Profitabilitas Terhadap Nilai Perusahaan Pada Sektor Properti Dan Real Estate. E-Jurnal Manajemen Universitas Udayana, 5(9), 5671-5694.

Purwohandoko. (2017). The Influence of Firm's Size, Growth, and Profitability on Firm Value with Capital Structure as the Mediator: A Study on the Agricultural Firms Listed in the Indonesian Stock Exchange. International Journal of Economics and Finance, 9(8), 103-110. https:// doi.org/10.5539/ijef.v9n8p103

Putri, R. W., \& Ukhriyawati, C. F. (2016). Pengaruh Likuiditas, Leverage dan Profitabilitas Terhadap Nilai Perusahaan Pada Perusahaan Telekomunikasi yang Terdaftar di Bursa Efek Indonesia Tahun 2012-2014. Jurnal Bening, 3(1), 52-73.

Rachmawati, D., \& Pinem, D. B. (2015). Pengaruh Profitabilitas, Leverage Dan Ukuran Perusahaan Terhadap Nilai Perusahaan. Equity, 18(1), 1-18. https:// doi.org/10.34209/equ.v18i1.456

Ramadhitya, G. K., \& Dillak, V. J. (2018). Pengaruh Profitabilitas, Leverage, Ukuran Perusahaan Dan Keputusan Investasi Terhadap Nilai Perusahaan (Studi Kasus pada Perusahaan Manufaktur Sub Sektor Makanan dan Minuman yang Terdaftar di Bursa Efek Indonesia Periode 2012-2016). EProceeding of Management, 5(3), 3589-3597.

Riaz, M., \& Qasim, M. (2016). Islamic Microfinance Institution: The Capital Structure, Growth, Performance and Value of The Firm in Pakistan. Journal of ISOSS, 2(1), 97-101.

Rizqia, D. A., Aisjah, S., \& Sumiati. (2013). Effect of Managerial Ownership , Financial Leverage, Profitability , Firm Size , and Investment Opportunity on Dividend Policy and Firm Value. Research Journal of Finance and Accounting, 4(11), 120-130.

Sabrin, Sarita, B., Takdir S., D., \& Sujono. (2016). The Effect of Profitability on Firm Value in Manufacturing Company at Indonesia Stock Exchange. The International Journal of Engineering and Science (IJES), 5(10), 81-89. https:// doi.org/10.1016/0014-4827(80)90264-5

Safitri, U. K. (2016). Pengaruh Profitabilitas dan Size Terhadap Nilai Perusahaan Dengan Struktur Modal Sebagai Variabel Intervening (Studi Empiris Pada Perusahaan Manufaktur Yang Terdaftar di Bursa Efek Indonesia Tahun 2011-2014). Universitas Muhammadiyah, 1-20.

Septariani, D. (2017). Pengaruh Kebijakan Dividen dan Kebijakan Hutang Terhadap Nilai Perusahaan (Studi Empiris pada Perusahaan LQ45 di BEI periode 2012-2015). Journal of Applied Business and Economics, 3(3), 183-195.

Sudiyatno, B., \& Puspitasari, E. (2010). Tobin's Q dan Altman Z-Score Sebagai Indikator Pengukuran Kinerja Perusahaan. Kajian Akuntansi, 2(1), 9-21.

Susanto, E. (2016). Pengaruh Profitabilitas, Kepemilikan Manajerial, Dan Pertumbuhan Perusahaan (Growth) Terhadap Struktur Modal dan Nilai Perusahaan. Jurnal STIE SEMARANG, 8(3), 1-20.

Tui, S., Nurnajamuddin, M., Sufri, M., \& Nirwana, A. (2017). Determinants of Profitability and Firm Value: Evidence from Indonesian Banks. IRAInternational Journal of Management $\mathcal{E}$ Social Sciences, 7(1), 84-95. https:// doi.org/10.21013/jmss.v7.n1.p10 
Wiagustini, N. L. P., Sedana, I. B. P., \& Badjra, I. B. (2017). Market Reaction and Semi Strong Efficiency Test. International Journal of Research in Commerce, Economics \& Management, 7(4), 1-6.

Yanti, I. G. A. D. N., \& Darmayanti, N. P. A. (2019). Pengaruh Profitabilitas, Ukuran Perusahaan, Struktur Modal, Dan Likuiditas Terhadap Nilai Perusahaan Makanan Dan Minuman. E-Jurnal Manajemen Universitas Udayana, $8(4)$, 2297-2324.

https://doi.org/10.24843/ejmunud.2019.v08.i04.p15 